\title{
Academy report backs 'science for all' plan
}

Washington. A radical overhaul of school science in the United States, with a far greater emphasis on 'understanding' and less on 'facts', is proposed in a draft set of national science education standards released last week by the National Research Council, the operating arm of the National Academy of Sciences (NAS).

The ambitious standards - - which the authors admit represent a long-term vision rather than a realistic short-term prospect call for all children at elementary, junior high and high school in the United States to reach a comprehensive and demanding level of scientific literacy.

They lay strong emphasis on the need for schoolchildren to understand concepts from an early age, rather than just learning facts and equations. Such concepts range from the nature of scientific enquiry to the relationship between science and health.

"We want to de-emphasize words and replace them with understanding," said Bruce Alberts, president of the academy and a long-standing advocate of improved science teaching, in unveiling the draft. He attacked the traditional teaching of science in US schools in forthright terms: "we fail to convey what science is, and we kill off the curiosity of the kids".

The draft, prepared at a cost of $\$ 6.5$ million, mostly paid for by the Department of Education and other US government agencies, says little about where resources would come from to pay for the expansion of science education implied in the proposed standards. But Alberts says that the commitment of parents, teachers and local school districts will be more important than extra money in implementing the standards.

The committee that drew up the document over the past two years was chaired by Richard Klausner, a senior cell biologist at the National Institutes of Health. He stresses that the standards are not an attempt by the federal government to impose uniformity on science education. "These are not federal standards, nor are they government standards," he says. "They are grass-roots standards, for the people who make decisions [on education] at the local level."

The document calls for greater participation by children in the learning process, and concedes that the teaching of very basic principles, such as the nature of an organism or the fact that all objects have properties, will involve a trade-off against the number of scientific 'facts' that children can learn. "If students are to understand the big ideas" of science, they will have less vocabulary, fewer topics, and reduced memorization of information," it says.

The content standards in the document call for a broad range of key principles to be taught to all pupils of all ages. In Earth and space science, for example - one of eight

domains to be taught to every student pupils in grades $\mathrm{K}$ to 4 (aged 5-9) are expected to learn to understand "properties of Earth materials" and "objects in the sky".

At grades 5 to 8 (aged 10-13) they should learn the "structure of the Earth system", "Earth's history", and "Earth in the Solar System". From grade 9 to 12 (aged 14-17), every teenager would learn more sophisticated concepts: energy in the Earth system, geochemical cycles, and the origin and evo-

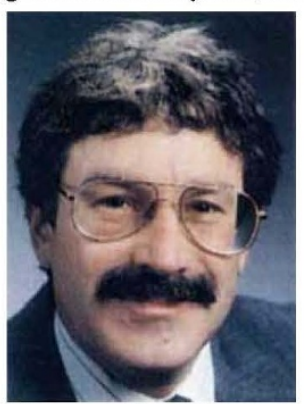

Klausner: 'no attempt to impose uniformity' lution of the Earth and the Universe.

Other domains include the history of science, and science and society, as well as the traditional fields of physical and life sciences. The document states unequivocally that none of these content elements are optional, and that each is necessary for a scientifically literate US population.

Challenged on the realism of such a goal, Klausner said that his panel "had to set a vision which is far from where we are now", and that the levels of scientific literacy laid out in the standards document were "not unrealistic".

The authors are optimistic that the science standards can avoid the kind of political controversy that has engulfed recent proposals for history teaching standards in the United States. For example, they steer cautiously around such awkward subjects as

creationism, saying that it should be addressed if raised by students.

Klausner denies that there is a 'back to basics' movement in US schools, and says that the progressive ideas in the document have widespread support from both parents and the local school districts that run the US school system. But Alberts concedes that some parents remain skeptical. "I'm convinced that if people really understood what we were talking about they would support it," he said. "But we have a big communications problem."

Around 30,000 copies of the standards draft will be circulated as part of a vast consultation process. Like other standards being proposed for schools, the science standards are the culmination of a process that began in earnest at the National Conference of State Governors in 1989.

The process is driven by a widespread fear that US school education is falling short of European standards and is well behind standards in the Far East. Many academics report that US college entrants are two years behind their overseas peers at the age of 18 , but that the well-organized and wealthy US university system makes up the ground lost in the schools.

But the proposed science standards focus less on potential college entrants than on achieving basic scientific literacy in the rest of the population, including those from disadvantaged backgrounds. Despite recent initiatives from the National Science Foundation and others (see Nature 369, 87; 1994), the state of school administration in many US cities will make that objective extremely difficult to meet.

Colin Macilwain

\section{OTA under threat from US Senate}

Washington. Robert Walker, a conservative Republican from Pennsylvania, is to chair the House of Representatives' committee that oversees most US federal science programmes when the new Congress meets in January. Walker, who lost a bid for his party's Whip position on Monday, will take over the Science, Space and Technology Committee formerly chaired by Democrat George Brown of California.

That committee also will get a new name - Technology and Competitiveness - intended to reflect the Republican majority's concern for economic issues. As a result of a re-shuffling of committee assignments, it will also assume greater responsibility for research programmes at the Department of Energy's national laboratories.

But the committee will maintain its oversight of both the National Aeronautics and Space Administration and the National Science Foundation, as well as civilian research at several smaller agencies. The $\mathrm{Na}$ - tional Institutes of Health will stay under the jurisdiction of the Commerce (formerly Energy and Commerce) Committee.

Although the most sweeping Congressional changes are likely to be in the House, Republicans in the Senate are also stirring things up as well. Last week, the Senate Republican Conference recommended that the Office of Technology Assessment (OTA), which provides independent advice to Congress on science and technology matters, should be abolished as a money-saving measure.

The attack, spearheaded by Senator Pete Domenici of New Mexico, caught OTA and its supporters by surprise. Although they believe OTA ultimately will be rescued in the appropriations process, the agency clearly will be on the defensive during the next session. "In this atmosphere, it's prove why you shouldn't be cut' rather than vice versa," says one Congressional staff member.

Tony Reichhardt 